\title{
Dampak Kepemimpinan Transformasional dan Kepuasan Kerja pada Organizational Citizenship Behavior (OCB)
}

\author{
Uswatun Hasanah
}

Email: uswatunhasanah2406@gmail.com

\begin{abstract}
Abstrak: Tujuan penelitian ini adalah untuk mengetahui deskripsi kepemimpinan transformasional kepala sekolah, kepuasan kerja, dan OCB; pengaruh kepemimpinan transformasional terhadap OCB; pengaruh kepuasan kerja terhadap OCB: dan pengaruh kepemimpinan transformasional kepala sekolah dan kepuasan kerja. Penelitian ini menggunakan pendekatan penelitian kuantitatif jenis ex-post facto. Populasi dalam penelitian ini adalah semua guru Sekolah Menengah Pertama (SMP) di Kecamatan Jerowaru Kabupaten Lombok Timur sebanyak 189 guru. Sampel penelitian sebanyak 85 guru yang diambil dengan tehnik sampling purposive. Data dianalisis mengunakan Teknik Deskriptif dan regresi ganda. Hasil penelitian ini menunjukkan bahwa kepemimpinan transformasioanl kepala sekolah tergolong kategori baik, kepuasan kerja tergolong kategori tinggi, dan OCB guru tergolong kategori tinggi; kepemimpinan transformasional kepala sekolah berpengaruh positif dan signifikan terhadap OCB; kepuasan kerja berpengaruh positif dan signifikan terhadap OCB; dan kepemimpinan transformasional kepala sekolah dan kepuasan kerja berpengaruh positif dan signifikan secara simultan terhadap OCB.
\end{abstract}

Keywords: Kepemimpinan Transformasional, Kepuasan Kerja, Organizational Citizenship Behavior

\section{PENDAHULUAN}

Pendidikan merupakan faktor yang sangat penting bagi kehidupan masyarakat. Untuk itu diperlukan upaya-upaya dalam menyelenggarakan pendidikan secara baik, tertata, dan sistematis sehingga proses yang terjadi dalam organisasi pendidikan seperti sekolah dapat menjadi suatu sumbangan besar bagi peningkatan kualitas kehidupan masyarakat. Pentingnya peran sekolah tersebut menjadikan guru sebagai salah satu faktor penting dalam meningkatkan kualitas pendidikan. ${ }^{1}$

${ }^{1}$ Bidang Pendayagunaan dan Pelayanan Data dan Statistik Pendidikan dan Kebudayaan. 2016. “Analisis Sumber Daya Manusia Pendidikan Dasar dan Menengah 2015/2016. Di akses Maret 
Namun kulaitas pendidikan di Indonesia khususnya di Nusa Tenggara Barat (NTB) masih dikatakan rendah. Rata-rata kinerja guru SMP di provinsi Nusa Tenggara Barat masih berada dibawah rata-rata nasional yakni 75,02 dari nilai 78,55. Selain itu, berdasarkan Analisis Kinerja Pendidikan Provinsi Nusa Tenggara Barat Tahun 2016 menunjukkan bahwa prestasi siswa di Provinsi NTB masih rendah. Hanya Kota Mataram yang memiliki rata-rata nilai UN > 66.00, sedangkan 8 kabupaten/kota lainnya mempunyai nilai rata-rata antara 46.00$66.00 .^{2}$

Kualitas pendidikan dapat dicapai secara efektif dan efisien apabila sekolah memiliki guru yang bekerja tidak hanya sesuai dengan perannya saja (in-role), melainkan cenderung kepada perilaku kerja yang melebihi perannya (extrarole). Perilaku kerja yang sesuai dengan tugas dan tanggung jawabnya disebut sebagai perilaku in-role, sedangkan perilaku kerja yang melebihi standar formal kerja disebut sebagai extra-role atau perilaku kerja ekstra. Hal-hal yang berkaitan dengan perilaku kerja ekstra dalam ilmu manajemen secara umum disebut dengan organizational citizenship behavior (OCB).

Menurut Organ (2006:31) OCB merupakan perilaku kerja yang melebihi perannya yang memberikan sesuatu lebih dari standar formal kerja. ${ }^{3}$ Dimensidimensi OCB menurut Organ (2005) dalam (Lubis 2015:31) yaitu Altruism (membantu), Civic virtue (proaktif), Concientiousness (ketaatan), Courtesy (kesopanan), dan Sportsmanship (toleransi). ${ }^{4}$ Adapun beberapa contoh OCB yang diharapkan untuk dilakukan seperti aktif dalam kegiatan-kegiatan sekolah, mencari informasi-informasi penting yang bermanfaat untuk mengembangkan sekolah, mengerjakan administrasi sekolah di rumah, taat pada kebijakankebijakan sekolah, dan meluangkan waktu setelah jam pulang sekolah untuk membantu siswa yang mengalami kesulitan belajar. Hal-hal tersebut tentu dapat

\footnotetext{
${ }^{2}$ Ibid.

${ }^{3}$ Organ, D.W., et.al. 2006. OrganizationalCitizenship Behavior. California:Sage Publications, Inc.

${ }^{4}$ Lubis, M.S. 2015. "Pengaruh Iklim Organisasi Dan Komitmen Organisasi Terhadap Pembentukan Organizational Citizenship Behavior (OCB) Karyawan Dalam Rangka Peningkatan Kinerja". E-jurnal apresiasi ekonomi. Volume 3(2) 75-84. stie-yappas.ac.id/e-jurnalapresiasiekonomi/jurnal/322.pdf.
} 
membantu dalam meningkatkan kualitas pendidikan. Oleh karena itu, untuk meningkatkan OCB guru, tentunya harus memperhatikan faktor-faktor yang mempengaruhinya. Namun pada kenyataannya OCB guru belum optimal. Hal ini diindikasikan dengan kurang aktifnya guru dalam mengahadiri kegiatan sekolah seperti kurang partisipatif dalam kegiatan pramuka, beberapa guru masih mengerjakan administrasi sekolah di sekolah, guru kurang inisiatif dalam memberikan kontribusi dalam perbaikan sekolah, dan masih ada beberapa guru yang telat datang kesekolah. Oleh karena itu, OCB penting untuk dioptimalkan.

Kepemimpinan kepala sekolah merupakan faktor utama dalam meningkatkan OCB guru, khususnya tipe kepemimpinan transformasional. Pendapat tersebut sejalan dengan pendapat Tschannen-Moran (2003: 52) bahwa salah satu tipe kepemimpinan yang mampu menggerakkan bawahannya melakukan pekerjaan melebihi perannya adalah kepemimpinan transformasional. ${ }^{5}$ Tipe pimpinan transformasional merupakan pemimpin yang memotivasi para pengikutnya untuk bekerja mencapai sebuah tujuan, bukan untuk kepentingan pribadi jangka pendek, dan untuk mencapai prestasi dan aktualisasi diri, dan bukan demi perasaan aman. Dengan mengekspresikan visinya, pemimpin transformasional mengajak pengikutnya untuk bekerja mencapai sebuah tujuan (Ivancevich et al, 2006: 213). ${ }^{6}$ Menurut Bass dan Riggio dalam (Hoy dan Miskel, 2014:669) indikator kepemimpinana kepala sekolah yang disebut dengan teori empat I yaitu pengaruh yang diidolakan, motiviasi inspirasional, rangsangan intelektual, dan pertimbangan individual. ${ }^{7}$

Kepemimpinan kepala sekolah yang efektif tentu akan diikuti oleh kepuasan kerja guru. Menurut Robbins \& Judge (2009: 107) kepuasan kerja adalah perasaan positif tentang pekerjaan seseorang yang merupakan hasil dari evaluasi

\footnotetext{
${ }^{5}$ Tschannen-moran, M. 2003. "Fostering Organizational Citizenship In School: Transformational Leadership And Trust". Journal Of Educational Administration. Chapter 6.pp. 1-36

${ }^{6}$ Ivancevich, J.M., Konopaske, R., Matteson, M.T. 2007. Perilaku dan Manajemen Organisasi Edisi Ketujuh. Jakarta: Penerbit Erlangga.

${ }^{7}$ Hoy, W.K., Miskel, C.G. 2014. Administrasi Pendidikan. Edisi 9. Yogyakarta: Pustaka Pelajar.
} 
karakteristiknya. ${ }^{8}$ Ketika guru merasakan kepuasan terhadap pekerjaan yang dilakukannya, maka guru tersebut akan bekerja secara maksimal dalam menyelesaikan pekerjaannya, bahkan melakukan beberapa hal yang mungkin di luar tugasnya. Hal-hal yang dilakukan di luar tanggung jawabnya secara tidak langsung berdampak positif dalam meningkatkan kualitas pendidikan. Adapun faktor yang mempengaruhi kepuasan kerja menurut Robbins dan Judge (2008:107) yaitu : pekerjaan itu sendiri, Pengawasan, gaji/upah, promosi, dan hubungan dengan rekan-rekan kerja. ${ }^{9}$

Berdasarkan latar belakang permasalahan tersebut, penelitian ini bertujuan untuk menegtahui bagaiamana kepemimpinan transformasional kepala sekolah, kepuasan kerja guru, dan organizational citizenship behavior guru serta pengaruh kepemimpinan transformasional kepala sekolah dan kepuasan kerja guru, terhadap organizational citizenship behavior guru baik secara parsial maupun secara simultan.

\section{METODE}

Pendekatan penelitian yang digunakan dalam penelitian ini adalah pendekatan kuantitatif dengan jenis ex-post facto. Populasi dalam penelitian ini adalah seluruh guru SMP di Kecamatan Jerowaru Kabupaten Lombok Timur Provinsi Nusa Tenggara Barat. yang berjumlah 15 Sekolah dengan jumlah guru sebanyak 189 orang guru dengan sampel 78 orang guru. Teknik pengambilan sampel yang digunakan adalah teknik sampling purposive. Instrument dalam penelitian ini berbentuk angket dengan 5 (lima) alternative jawaban berdasarkan skala likert yang telah memenuhi uji validitas dan reliabilitas. Angket dalam penelitian ini dirancang sendiri oleh peneliti berdasarkan indikator masing-masing variabel. Indikator kepemimpinan transformasional merujuk pada teori empat I Bass dan Riggio. Adapun yang menjadi indikator kepuasan kerja dalam penelitian ini merujuk pada teori Robbins dan Judge. Sedangkan indikator OCB guru dalam

${ }^{8}$ Robbins, S. \& Judge, T. 2009. Perilaku Organisasi EdisiKedua Belas. Jakarta: Salemba Empat:Jakarta

${ }^{9}$ Robbins, S. \& Judge, T. 2008. Perilaku Organisasi EdisiKedua Belas. Jakarta: Salemba Empat:Jakarta 
penelitian ini merujuk pada teori Organ. Angket kemudian dilakukan uji validitas dan uji reliabiltas. Analisis data yang digunakan dalam penelitiann ini adalah analisis deskriptif dan analisis regresi, baik analisis regresi sederhana maupun regresi ganda. Analisis deskriptif digunakan untuk mendeskripsikan kepemimpinan transformasional, kepuasan kerja, dan OCB. Sedangkan analisis regresi digunakan untuk mengetahui apakah ada pengaruh variabel bebas terhadap variabel terikat. Untuk mengetahui pengaruh tersebut, terlebih dahulu dilakukan uji asumsi seperti uji normalitas, uji autokorelasi, uji homogenitas, dan uji multikolinieritas. Kemudian uji hipotesis menggunakan uji regresi linier ganda atau uji $\mathrm{t}$ untuk mengetahui pengaruh secara parsial antara kepemimpinan transformasional $\left(\mathrm{X}_{1}\right)$, kepuasan kerja $\left(\mathrm{X}_{2}\right)$, sebagai variabel bebas terhadap organizational citizenship behavior (Y) sebagai variabel terikat. Selain uji t, dilakukan juga uji $F$ untuk mengetahui dampak secara simultan antara kepemimpinan transformasional $\left(\mathrm{X}_{1}\right)$ dan kepuasan kerja $\left(\mathrm{X}_{2}\right)$ terhadaporganizational citizenship behavior $(\mathrm{Y})$.

\section{HASIL DAN PEMBAHASAN}

\section{Hasil}

Berdasarkan karakteristik responden dapat diketahui bahwa dalam penelitian ini responden laki-laki berjumlah 40 orang dan responden perempuan berjumlah 38 orang. Jumlah guru berstatus PNS sebanyak 27 orang dan guru tidak tetap (GTT) sebanyak 51 orang. Guru yang berstatus PNS dari pangkat golongan IIC sampai dengan IVA. Perbedaan status tersebut tentu berdampak pada upah/gaji yang diterima. Perbedaan upah/gaji dapat berpengaruh terhadap kepuasan kerja. Adapun lama mengajar guru dibagi menjadi 4 (empat ) kelompok, guru yang mengajar kurang dari 5 tahun sebanyak 23 orang, guru yang mengajar selama 5-10 tahun sebanyak 29 orang, guru yang mengajar antara 11-15 tahun sebanyak 22 orang, dan guru yang mengajar lebih dari 15 tahun sebanyak 4 orang. Perbedaan lama mengajar tersebut menunjukkan persebaran guru dari guru baru hingga guru yang senior, yang sudah memiliki pengalaman dalam mengajar. Hampir semua guru merupakan lulusan S1 (Strata 1). Hal tersebut menunjukkan 
bahwa syarat menjadi guru sudah terpenuhi. Menurut Rahayuningsih dan Solikhin (2015: 193) kemampuan seorang guru dipengaruhi oleh latar belakang pendidikannya sebagai modal dasar. Semakin tinggi pendidikan seseorang, maka semakin mampu orang yang bersangkutan untuk melaksanakan tugas dan pekerjaan yang diembannya. Mangkunagera (2004: 120) juga menyebutkan bahwa tingkat pendidikan dapat mempengaruhi kepuasan kerja seseorang.

Adapun karakteristik lain dari responden dalam penelitian ini adalah bahwa resonden merupakan guru yang mengajar pada mata pelajaran yang berbeda. Jumlah guru yang mengajar bidang studi ilmu pengetahuan alam (IPA) sebanyak 9 orang, ilmu pengetahuan social (IPS) sebanyak 10 orang, Bahasa Inggris sebanyak 9 orang, Bahasa Indonesia sebanyak 8 orang, Matematika sebanyak 13 orang, guru pendidikan agama islam (PAI) Sebanyak 6 orang, guru Pendidikan Kewarganegaraan (PKn) sebanyak 5 orang, guru pendidikan jasamani dan kesehatan (Penjaskes) sebanyak 5 orang, guru seni budaya (SBD) dan muatan lokal (mulok) sebanyak 6 orang, guru teknologi informasi dan komunikasi (TIK) sebanyak 4 orang, dan guru bimbingan konseling (BK) sebanyak 3 orang. Perbedaan responden berdasarkan mata pelajaran yang diajarkan oleh tersebut berhubungan dengan kepuasan kerja, karena salah satu indikator kepuasan kerja adalah tingkat kesulitan dari masing-masing pekerjaan.

Deskripsi variabel kepemimpinan transformasional kepala sekolah menunjukkan bahwa total skor rata-rata sebesar 78, sehingga termasuk dalam kategori baik. Adapun perbedaan persepsi kepemimpinan transformasional kepala sekolah antara guru laki-laki dan guru perempuan menunjukkan bahwa bahwa guru laki-laki mempersepsikan dengan baik kepemimpinan kepala sekolah, sedangkan guru perempuan mempersepsikan dengan sangat baik kepemimpinan kepala sekolah Total skor rata-rata untuk variabel kepuasan kerja sebesar 79 yang termasuk dalam kategori tinggi. Deskripsi kepuasan kerja menunjukkan bahwa guru laki-laki puas atas pekerjaannya, sedangkan guru perempuan merasa sangat puas atas pekerjaan yang dilakukan. Sedangkan untuk variabel OCB sendiri memiliki total skor rata-rata sebesar 80 sehingga termasuk dalam kategori sangat tinggi. Guru perempuan dan laki-laki menunjukkan OCB dalam kategori tinggi. 
Indikator kepemimpinan transformasional kepala sekolah yang memiliki nilai rata-rata tertinggi adalah indikator pengaruh yang diidolakan dengan rata-rata mencapai 82,7. Sedangkan indikator kepemimpinan transformasional dengan penilaian terendah adalah indikator pertimbangan individual dengan nilai rata-rata sebesar 75,1. Indikator kepuasan kerja dengan rerata tertinggi adalah indikator teman kerja dengan nilai rata-rata sebesar 83,6. Sedangkan indikator kepuasan kerja dengan rerata terendah yaitu indikator upah/gaji dengan rata-rata 72,1. Indikator OCB yang memiliki nilai rata-rata tertinggi adalah indikator conscientiousness (ketaatan) dengan nilai rata-rata sebesar 84,9. Sedangkan indikator OCB dengan nilai rata-rata terendah adalah indikator civic virtue (proaktif) dengan rata-rata 77,8 .

Sebelum melakukan pengujian hipotesis, terlebih dahulu dilakukan uji asumsi klasik. Dari hasil pengujian diperoleh bahwa 1) data berdistribusi normal, ditandai dengan titik-titik pada gambar p-plots mengikuti garis lurus, 2) tidak ada sifat multikolinieritas, ditunjukkkan dengan nilai VIF lebih kecil dari 10, dan nilai tolerance lebih besar dari 0,1.3) ragam homogen, ini dibuktikan dengan titik-titik yang menyebar pada sumbu X dan Y serta tidak membentuk pola tertentu, dan 4) tidak terdapat sifat autokorelasi, ditunjukkan dengan nilai Durbin Watson sebesar 1,68. Dengan demikian model regresi layak digunakan dalam penelitian.

Tabel 1: Pengaruh Kepemimpinan Kepala Sekolah, Kepuasan Kerja Secara Parsial terhadap OCB.

\begin{tabular}{lllllll}
\hline Variabel Bebas & $\mathrm{t} / \mathrm{F}_{\text {tabel }}$ & $\mathrm{t} / \mathrm{F}_{\text {hitung }}$ & Sig. & Konstanta & Koefisien & $\mathrm{R}$ \\
& & & regresi (a) & regresi & square
\end{tabular}

(b)

\begin{tabular}{lrrrrrr}
\hline Kepemimpinan & 1,992 & 7,790 & 0,000 & 32,041 & 0,629 & 0,444 \\
$\begin{array}{l}\text { Kepala Sekolah } \\
\text { Kepuasan Kerja }\end{array}$ & 1,992 & 5,971 & 0,000 & 27,123 & 0,689 & 0,319 \\
\begin{tabular}{l} 
Variabel terikat : OCB \\
\hline
\end{tabular}
\end{tabular}

Berdasarkan hasil penelitian dihasilkan bahwa kepemimpinan transformasional kepala sekolah berpengaruh dan signifikan terhadap OCB guru. 
Hal tersebut dibuktikan dengan nilai $t_{\text {hitung }}$ sebesar 7.790 lebih besar daripada nilai $\mathrm{t}_{\text {tabel }}$ sebesar 1,992 dengan nilai signifikan lebih kecil dari taraf signifikans 0,05 yakni sebesar 0,000. Kemudian Kepuasan kerja juga berpengaruh positif dan signifikan terhadap OCB guru. Hasil analisis menunjukkan bahwa nilai $t_{\text {hitung }}$ lebih besar daripada nilai $t_{\text {tabel }}$ yakni 1,992 $<5,971$ dengan nilai signifikan lebih kecil dari 0,05 yakni sebesar 0,000.

Nilai koefisien regresi $b$ variabel kepemimpinan transformasional kepala sekolah sebesar 0,629, dan konstanta (intercept) a sebesar 32,041. Dengan demikian, bentuk persamaan regresi kepemimpinan transformasional kepala sekolah $\left(\mathrm{X}_{1}\right)$ terhadap OCB guru adalah $\hat{Y}=32,041+0,629 X_{1}$. Artinya bahwa, perubahan satu unit persepsi pada peubah kepemimpinan kepala sekolah diikuti oleh perubahan OCB guru sebesar 0,629 unit pada arah yang sama dengan intercept sebesar 32,041. Adapun besar pengaruh kepemimpinan kepala sekolah terhadap OCB guru dari nilai $\mathrm{R}^{2}$ sebesar 0,444. Artinya bahwa kepemimpinan kepala sekolah mempunyai pengaruh sebesar $44,4 \%$ terhadap OCB guru.

Koefisien regresi $b$ variabel kepuasan kerja sebesar 0,689 dan konstanta (intercept) a sebesar 27,123. Dengan demikian, pengaruh kepuasan kerja guru $\left(\mathrm{X}_{2}\right)$ terhadap OCB guru $(\mathrm{Y})$ dapat dirumuskan dengan persamaan $\hat{Y}=27,123+$ $0,689 X_{2}$. Artinya bahwa perubahan satu unit persepsi pada peubah kepuasan kerja guru diikuti oleh perubahan OCB guru sebesar 0,689 unit dengan intercept sebesar 27,123. Adapun besar pengaruh kepuasan kerja guru terhadap OCB guru sebesar 0,319. Artinya Kepuasan kerja guru memiliki pengaruh sebesar 31,9\% terhadap OCB guru.

Tabel 2: Pengaruh Kepemimpinan Kepala Sekolah dan Kepuasan Kerja Secara Simultan terhadap OCB.

Model

\begin{tabular}{lrrrrr} 
& Sum of Squares & Df & Mean Square & F & Sig. \\
\hline Regresi & 4568.231 & 2 & 2284.116 & 41.467 & $.000^{\mathrm{a}}$ \\
\hline
\end{tabular}


Berdasarkan Tabel 2 di atas, nilai $\mathrm{F}_{\text {hitung }}$ sebesar 41,467 lebih besar daripada $F_{\text {tabel }}$ sebesar 3,12. Dengan demikian, dapat disimpulkan bahwa terdapat pengaruh positif kepemimpinan kepala sekolah dan kepuasan kerja guru secara bersamasama terhadap OCBguru.Nilai signifikan diperoleh sebesar 0,000 lebih kecil daripada 0,05 (Sig.<0,05) yang bermakna bahwa terdapat pengaruh yang signifikan antara kepemimpinan kepala sekolah dan kepuasan kerja guru secara bersama-sama terhadap OCBguru.

Tabel 3. Hasil Analisis Regresi Ganda Pengaruh $\mathrm{X}_{1}$ dan $\mathrm{X}_{2}$ terhadap $\mathrm{Y}$.

\begin{tabular}{|c|c|c|c|c|}
\hline \multirow[b]{2}{*}{ Model } & \multicolumn{2}{|c|}{ Koefisien } & \multirow[b]{2}{*}{$t_{\text {hitung }}$} & \multirow[b]{2}{*}{ Sig. } \\
\hline & $\mathrm{B}$ & Std. Error & & \\
\hline Konstan $(a)$ & 15,626 & 10.081 & & \\
\hline $\begin{array}{l}\text { Kepemimpinan Kepala } \\
\text { Sekolah }(b 1)\end{array}$ & .453 & .079 & 5.725 & .000 \\
\hline Kepuasan Kerja Guru (b2) & .405 & .115 & 3.537 & .001 \\
\hline
\end{tabular}

BerdasarkanTabel 3, koefisien arah regresi $b 1$ sebesar 0,453, arah regseri $b 2$ sebesar 0,405, dan arah konstanta (intercept) a sebesar 15,656. Dengan demikian, pengaruh kepemimpinan transformasional kepala sekolah $\left(\mathrm{X}_{1}\right)$ dan kepuasan kerja $\left(\mathrm{X}_{2}\right)$ secara bersama-sama terhadap OCB guru $(\mathrm{Y})$ dirumuskan dengan persamaan $\hat{Y}=15,656+0,453 X_{1}+0,405 X_{2}$. Artinya bahwa: 1) Perubahan satu unit persepsi pada kepemimpinan transformasional kepala sekolah $\left(\mathrm{X}_{1}\right)$ dengan faktor kepuasan kerja dianggap konstan, maka akan diikuti oleh perubahan OCB guru (Y) sebesar 0,453 unit pada intercept sebesar 15,656. 2) Perubahan satu unit pada kepuasan kerja guru $\left(\mathrm{X}_{2}\right)$ dan faktor kepemimpinan kepala sekolah dianggap konstan, maka akan diikuti oleh perubahan OCB guru (Y) 0,327 pada intercept sebesar 15,656. Adapun besar pengaruh kepemimpinan kepala sekolah dan kepuasan kerja guru secara bersama-sama terhadap OCBguru diperoleh berdasarkan nilai $\mathrm{R}^{2}$. Nilai $\mathrm{R}^{2}$ diperolehsebesar 0,525. Artinya bahwa, kepemimpinan kepala sekolah dan kepuasan kerja guru secara bersama-sama 
berpengaruh sebesar $52,5 \%$ terhadap OCB guru, sedangkan sisanya dipengaruhi oleh faktor lain.

\section{Pembahasan}

\section{Pengaruh Kepemimpinan Transformasional Kepala Sekolah terhadap OCB Guru SMP di Kecamatan Jerowaru}

Kepemimpinan transformasional yang dilaksanakan oleh kepala sekolah di SMP Kecamatan Jerowaru tergolong kategori baik. Namun kepemimpinan kepala sekolah apabila dilihat berdasarkan persepsi guru laki-laki dan guru perempuan memiliki perbedaan. Sebagian besar guru perempuan mengkategorikan kepemimpinan kepala sekolah dalam kategori sangat baik, sedangkan sebagian besar guru laki-laki mengkategorikan kepemimpinan kepala sekolah dalam kategori baik. Kepemimpinan kepala sekolah yang baik dan efektif tentu mampu mempengaruhi guru untuk bekerja maksimal bahkan bekerja melebihi dari apa yang diharapkan. Berdasarkan hasil penelitian, kepemimpinan kepala sekolah di SMP Kecamatan Jerowaru memiliki pengaruh positif dan signifikan terhadap OCB guru. Adanya pengaruh kepemimpinan transformasional kepala sekolah terhadap OCB guru tentunya disebabkan karena kepala sekolah di SMP Kecamatan Jerowaru sudah dengan baik melaksanakan indikator-indikator kepemimpinan transformasional. Temuan penelitian ini sejalan dengan hasil penelitian yang dilakukan oleh Putranti dan Kurniady (2013) ${ }^{10}$, Rahmi (2013) ${ }^{11}$, Rafizi (2013) ${ }^{12}$, Nasra dan Heilbrun

\footnotetext{
${ }^{10}$ Putranti, A.D., Kurniady, D.A. 2013. "Kontribusi Kepemimpinan Transformasional Kepala Tk dan Kepuasan Kerja Guru Terhadap Organizational Citizenship Behavior (OCB) Guru Tk Se-Kabupaten Kudus. Jurnal Administrasi Pendidikan. Vol. XVII No.1, 1-11

${ }^{11}$ Rahmi. 2013. "Pengaruh Kepemimpinan Transformasional Terhadap Organizational Citizenship Behavior Dan Komitmen Organisasi Dengan Mediasi Kepuasan Kerja”. Jurnal Manajemen Universitas Udayana. 331-350.

${ }^{12}$ Rafizi. 2013. "Pengaruh Kepemimpinan Transformasional Dan Kepuasan Kerja Terhadap Perilaku Kewargaan Guru Sekolah Menengah Di Sungailiat, Kabupaten Bangka".Tesis: Universitas Terbuka.
} 
$(2014)^{13}$, Ali et al $(2015)^{14}$, dan Nadeak $(2016)^{15}$, yang menyimpulkan bahwa kepemimpinan kepala sekolah khususnya kepemimpinan transformasional mempunyai pengaruh yang positif dan signifikan terhadap OCB.

Kepemimpinan transformasional kepala sekolah akan efektif apabila kepala sekolah mampu melaksanakan indikator-indikator kepemimpinan dengan tepat. Indikator kepemimpinan dalam penelitian ini adalah 1) pengaruh yang diidolakan, 2) motivasi inspirasional, 3) rangsangan intelektual, dan 4) pertimbangan individual. Hasil penilaian guru terhadap kepemimpinan transformasional kepala sekolah di SMP Kecamatan Jerowaru menunjukkan bahwa indikator yang sudah dilakukan dengan sangat baik oleh kepala sekolah adalah indikator "pengaruh yang diidolakan". Ini berarti kepala sekolah di SMP Kecamatan Jerowaru sudah dengan sangat baik dalam menumbuhkan kepercayaan dan penghormatan pada guru, memberikan standar pada guru dalam bekerja, meyakinkan guru dalam menyelesaikan persoalan-persolan penting, memperlihatkan standar perilaku etis dan moral yang tinggi, berbagi resiko dengan guru dalam mencapai tujuan, mengutamakan kepentingan guru, dan mampu memanfaatkan kekuasaan untuk menggerakkan guru dalam pencapaian visi dan misi sekolah.

Nilai rata-rata tiga indikator kepemimpinan transformasional kepala sekolah yang lain belum maksimal. Hal tersebut bermakna bahwa indikator tersebut sudah dilaksanakan dengan baik namun belum dilaksanakan secara

${ }^{13}$ Nasra, M.A., Heilbrunn, Syibille. 2015. "Transformational Leadership And Organizational Citizenship Behavior In The Aarab Educational System In Israel”. Jurnal Educational Administration And Leadership.

${ }^{14}$ Ali, Nazim., Ali, Shahid., Ahsan, Anjum., Rahman, Wili., Kakakhel, Shahid Jan. 2014. "Effects of Leadership Styles on Job Satisfaction, Organizational Citizenship Behavior, Commitment and Turnover Intention (Empirical Study of Private Sector Schools' Teachers)". Life Scince Journal. Vol.11 No 4(s).

${ }^{15}$ Nadeak, G.B. 2016. "The Effect Of The Cultural Organization, Leadership, Job Satisfaction, And Organizational Citizenship Behavior Lecturer In The Christian University Of Indonesia”. Jurnal Ilmiah Educational Management. Volume 7 Nomor 1. 1254-1262. pps.unj.ac.id/journal/jiem/article/view/216. 
maksimal oleh kepala SMP Kecamatan Jerowaru. Indikator-indikator tersebut seperti motivasi inspirasional, rangsangan intelektual dan indikator pertimbangan individual. Indikator pertimbangan individual merupakan indikator dengan nilai rata-rata paling rendah dibandingkan dengan rata-rata indikator yang lain. Hal ini menunjukkan bahwa kepala sekolah belum efektif dalam memberikan perhatian khusus akan prestasi dan kebutuhan masingmasing guru, membantu guru untuk berkembang menuju potensi yang lebih tinggi, menciptakan kesempatan belajar yang baru dalam iklim yang mendukung, memberikan pengakuan dan penerimaan perbedaan kebutuhan dan nilai individual masing-masing guru, menggunakan komunikasi dua arah dengan guru dan menyimak bawahan secara aktif dan efektif.

Rendahnya penilaian guru terhadap indikator pertimbangan individual tersebut didukung oleh hasil observasi dan wawancara dengan guru yang berpendapat bahwa beberapa kepala sekolah kurang memberikan perhatian kepada guru, khususnya pada sekolah swasta. Hal tersebut dikarenakan ada kepala sekolah SMP swasta merupakan guru yang berstatus sebagai PNS di sekolah lain, sehingga berdampak pada kurang efektifnya perhatian kepala sekolah terhadap bawahannya seperti kurang memberikan perhatian khusus akan prestasi dan kebutuhan masing-masing guru, kurang memberikan pengakuan, penerimaan perbedaan dan kebutuhan nilai individual masingmasing guru, serta kurang efektifnya komunikasi dua arah antara guru dan kepala sekolah.

\section{Pengaruh Kepuasan Kerja terhadap OCB Guru SMP di Kecamatan Jerowaru}

Berdasarkan hasil penelitian, kepuasan kerja guru berpengaruh positif dan signifikan terhadap OCB guru. Penelitian ini di dukung hasil penelitian Putranti dan Kurniady (2013), Rahmi (2013), Rafizi (2013), Nadeak (2016), dan Rahmawati (2017) ${ }^{16}$ yang menyimpulkan bahwa kepuasan kerja
${ }^{16}$ Rahmawati,
$\mathrm{T}$.
Prasetya,
A.
2017.

“Analisis Faktorfaktor yang Mempengaruhi Organizational 
berpengaruh positif dan signifikan terhadap perilaku kerja ekstra guru. Robbins (2007: 103) menyatakan bahwa seseorang dengan tingkat kepuasan tinggi menunjukkan sikap positif terhadap pekerjaan itu, sebaliknya seseorang yang tidak puas dengan pekerjaannya akan menunjukkan sikap negatif terhadap pekerjaannya. ${ }^{17}$ Ketika guru merasakan kepuasan terhadap pekerjaan yang dilakukan, maka guru tersebut akan bekerja secara maksimal dalam menyelesaikan pekerjaannya, bahkan melakukan beberapa hal di luar tugasnya yang secara tidak langsung berdampak positif dalam mencapai tujuan-tujuan sekolah. Oleh karena itu dapat disimpulkan bahwa peningkatan OCB guru dapat ditingkatkan dengan meningkatkan kepuasan kerja guru.

Kepuasan kerja guru SMP di Kecamatan Jerowaru tergolong kategori puas. Namun kepuasan kerja guru apabila dilihat dari jenis kelamin responden memiliki perbedaan. Guru perempuan berpendapat lebih puas atas pekerjaannya dibandingkan guru laki-laki. Ini membuktikan bahwa kepuasan kerja guru berbeda antara guru yang sau dengan yang lain. Hal tersebut sejalan dengan pendapat Hamidi (2016: 16) bahwa kepuasan kerja berhubungan dengan perasaan seseorang yang menyenangkan dan tidak menyenangkan, oleh karena perasaan tersebut dirasakan oleh seseorang sebagai individu maka kepuasan kerja seseorang bisa berbeda dengan orang lain. ${ }^{18}$ Selain itu, Susilowati (2009:3) menyatakan bahwa, kepuasan kerja pada dasarnya

Citizenship Behavior (OCB) pada Karyawan Tetap dan Karyawan Kontrak. Jurnal Administrasi Bisnis (JAB). Vol. 48 No.1. 97-106.

${ }^{17}$ Robbins, S.P., Coulter, M. 2007.Manajemen Edisi Kesepuluh. Jakarta : Erlangga ${ }^{18}$ Hamidi. 2016. "Pengaruh Kualitas Kehidupan Kerja dan Kinerja Guru terhadap Kepuasan Kerja Guru SMA Negeri di Kota Mataram”. TesisMagister Administrasi Pendidikan. Program Pascasarjana Universitas Mataram Hoy, W.K., Miskel, C.G. 2014. Administrasi Pendidikan. Edisi 9. Yogyakarta: Pustaka Pelajar. 
merupakan hal yang bersifat individual, setiap individu akan memiliki tingkat kepuasan yang berbeda-beda dengan sistem nilai yang berlaku pada dirinya. ${ }^{19}$

Perbedaan kepuasan kerja guru tersebut tentu karena indikator-indikator kepuasan kerja belum terpenuhi dengan maksimal. Adapun indikator yang digunakan untuk mengukur kepuasan kerja dalam penelitian ini adalah 1) pekerjaan itu sendiri, 2) atasan/supervise, 3) gaji/upah, 4) promosi, dan 5) teman kerja. Indikator kepuasan kerja yang memiliki nilai rata-rata dengan kategori sangat memuaskan adalah indikator pekerjaan itu sendiri dan indikator teman kerja. Hal tersebut menunjukkan bahwa indikator pekerjaan itu sendiri sudah terpenuhi dengan maksimal. Adapun beberapa contohnya seperti keahlian yang dimiliki guru sesuai dengan bidang studi yang diajarkan, tingkat kesulitan pekerjaan sesuai dengan kemampuan guru, dan guru merasa keahliannya dibutuhkan dalam melakukan suatu pekerjaan. Selain itu, indikator teman kerja juga sudah dirasakan memuasakan oleh guru, seperti hubungan guru dengan pimpinan maupun hubungan guru dengan rekan kerja, dukungan dan perhatian pimpinan maupun rekan kerja sudah dirasakan sangat memuaskan oleh guru.

Indikator kepuasan kerja yang lain dapat dikatakan belum memuaskan dirasakan oleh guru. Indikator tersebut seperti supervise/atasan, promosi, dan gaji/upah. Penilaian tersebut sejalan dengan hasil observasi dan wawancara bahwa kepala sekolah khususnya kepala sekolah swasta belum efektif dalam melaksanakan kepemimpinannya, seperti kurang memberikan bantuan teknis dan perilaku dukungan bagi guru. Adapun indikator dengan nilai rata-rata terendah adalah indikator upah/gaji. Ini menunjukkan bahwa indikator kepuasan kerja gaji/upah belum memberikan kepuasan maksimal bagi guru. Rendahnya nilai rata-rata tersebut tentu dikarenakan karena sebagian besar responden merupakan guru dengan status guru tidak tetap (GTT). Guru yang berstatus GTT tentu mendapat kompensasi yang berbeda dengan guru yang

\footnotetext{
${ }^{19}$ Susilowati. 2009. "Pengaruh Kepemimpinan, Lingkungan Kerja, Pengembangan Karir, Komunikasi Dan Insentif Terhadap Kepuasan Kerja Guru Sma Negeri I Cawas Kabupaten Klaten”. Exellent. (2).1.pp. 1-23.
} 
berstatus PNS. Hal tersebut sejalan dengan penelitian yang dilakukan oleh Siregar (2011) yang menyatakan bahwa sistem kompensasi finansial berpengaruh positif terhadap kepuasan kerja guru, artinya sistem kompensasi finansial yang tinggi mengakibatkan peningkatan kepuasan kerja. ${ }^{20}$ Selain itu, penelitain Firmansyah (2008) juga menyimpulkan bahwa kompensasi berpengaruh signifikan terhadap kepuasan kerja guru. ${ }^{21}$

\section{Pengaruh Kepemimpinan Kepala Sekolah dan Kepuasan Kerja terhadap OCB Guru SMP di Kecamatan Jerowaru}

Organizational citizenship behavior guru di Kecamatan Jerowaru tergolong kategori tinggi. Hasil penelitian juga menunjukkan bahwa tidak ada perbedaan antara OCB guru laki-laki dan guru perempuan. Hal tersebut sejalan dengan hasil penelitian yang dilakukan oleh Sari (2017) $)^{22}$ dan Rahman (2014) ${ }^{23}$ yang menyatakan bahwa tidak ada perbedaan OCB ditinjau dari jenis kelamin guru. Hasil penelitian inimenunjukkan bahwa kepemimpinan transformasional kepala sekolah dan kepuasan kerja secara bersama-sama berpengaruh positif dan signifikan terhadap OCB guru SMP di Kecamatan Jerowaru. Adanya pengaruh secara positif dan signifikan tersebut menunjukkan bahwa kepemimpinan transformasional kepala sekolah dan kepuasan kerja dalam penelitian ini sudah dilaksanakan dengan baik oleh kepala sekolah dan guru sehingga mampu menumbuhkan OCB guru SMP di Kecamatan Jerowaru. Selain itu, ketiga faktor tersebut merupakan faktor yang sangat penting dan

${ }^{20}$ Siregar, Edi.2011. Pengaruh Motivasi Kerja, Kinerja Individual, dan Sistem Kompensasi Finansial Terhadap Kepuasan Kerja. Jurnal Pendidikan Penabur, 16, $h: 81-93$

${ }^{21}$ Firmansyah, Farid. 2008. Pengaruh Lingkungan Kerja, Kompensasi, dan Kepemimpinan terhadap Kepuasan Kerja guru dan Karyawan SMA Wachid Hasyim Surabaya. Tadris Jurnal Pendidikan Islam. Vol. 3 No.1.

${ }^{22}$ Sari, D.P. 2017. Organizational Citizenship Behavior (OCB) pada Guru SMPN Sub Rayon-02 di Kabupaten Semarang Ditinjau dari Jenis Kelamin. Institutional Repository. Satya Wacana Christian University.

${ }^{23}$ Rahman, Ulfiani. 2014. Kepuasan Kerja dan Organizational Citizenship Behavior Pada Guru Madrasah Aliyah Madani Alauddin Paopao Gowa Sulawesi Selatan. Jurnal Analisa. Vol. 21 No.1. 
dominan dalam menumbuhkan OCB guru.Hasil penelitian ini konsisten dengan teori-teori yang mendasarinya serta temuan-temuan sebelumnya yaitu penelitian yang dilakukan oleh Putranti dan Kurniady (2013), Rahmi (2013), dan Rafizi (2013) yang menyimpulkan bahwa kepemimpinan transformasional dan kepuasan kerja berpengaruh signifikan secara bersama-sama terhadap OCB. Penelitian lain yang sejalan dengan penelitian ini juga dilakukan oleh Nadeak (2016) yang menyimpulkan bahwa budaya organisasi, kepemimpinan, dan kepuasan kerja berpengaruh secara signifikan terhadap OCB.

Indikator OCB guru yang digunakan dalam penelitian ini adalah altruism (perilaku membantu rekan kerja), civic virtue (perilaku proaktif), concientiousness (perilaku ketaatan), courtesy (perilaku kesopanan), dan sportsmanship (perilaku toleransi). Indikator OCB dengan nilai rata-rata tertinggi adalah indikator concientiousness (perilaku ketaatan). Indikator tersebut berarti sudah dilaksanakan dengan sangat baik oleh guru. Adapun contoh perilaku conscientiousness yang sudah dilaksanakan sangat baik oleh guru seperti menaati tata tertib sekolah, tidak meninggalkan sekolah saat jam pelajaran, dan tepat waktu dalam menghadiri kegiatan sekolah. Indikator OCB yang memiliki nilai rata-rata paling rendah adalah indikator civic virtue (perilaku proaktif). Hal ini berarti bahwa indikator tersebut belum ditunjukkan secara optimal oleh guru. Adapun contoh perilaku proaktif yang belum maksimal seperti guru belum maksimal dalam mengikuti perubahan dan perkembangan-perkembangan dalam sekolah, guru kurang maksimal dalam memberikan inisiatif untuk rekomendasi perbaikan terhadap sekolah, dan guru belum secara maksimal ikut menjaga sumber daya yang dimiliki oleh sekolah. Hal tersebut sesuai dengan hasil wawancara dengan kepala sekolah SMP di Kecamatan Jerowaru yang menyatakan bahwa masih ada beberapa guru yang tidak menjaga dengan baik barang-barang milik sekolah, bahkan ada guru yang membawa pulang barang-barang milik sekolah.

Indikator-indikator OCB tersebut tentu perlu dioptimalkan dengan memperhatikan faktor-faktor yang dapat meningkatkan OCB itu sendiri. Berdasarkan hasil penelitian, kepemimpinan transformasional kepala sekolah, 
kepuasan kerja guru berpengaruh secara parsial dan simultan terhadap OCB guru SMP di Kecamatan Jerowaru. Namun, jika dilihat dari kontribusi yang diberikan diyakini terdapat faktor-faktor lain yang mempengaruhi OCB guru SMP di Kecamatan Jerowaru. Ketiga variabel bebas dalam penelitian ini memberikan kontribusi sebesar 52,5\% terhadap OCB guru. Hal ini berarti sebesar 47,5\% OCB guru dipengaruhi oleh faktor lain. Adapun faktor yang dapat mempengaruhi perilaku kerja ekstra guru menurut Organ dan Sloat dalam Lubis (2015: 32) adalah faktor budaya dan iklim organisasi, kepribadian, suasana hati, dukungan organisasional, kualitas interaksi atasan-bawahan, masa kerja dan jenis kelamin. Selain itu, menurut Luthans (2006: 654) OCB memiliki hubungan yang sangat jelas dengan motivasi, kepuasan kerja, dan komitmen organisasi. Apabila faktor-faktor tersebut terpenuihi, maka OCB guru akan berjalan secara optimal. ${ }^{24}$

\section{SIMPULAN DAN SARAN}

\section{Simpulan}

Berdasarkan hasil yang diperoleh dalam penelitian ini maka dapat ditarik kesimpulan 1) Kepemimpinan transformasional kepala sekolah di SMP Kecamatan Jerowaru tergolong kategori baik, kepuasan kerja guru di SMP Kecamatan Jerowaru tergolong tinggi, dan OCB guru SMP di Kecamatan Jerowaru tergolong tinggi. 2) Kepemimpinan transformasional kepala sekolah berpengaruh positif dan signifikan terhadap OCB guru SMP di Kecamatan Jerowaru sebesar 44,4\%. 3) Kepuasan kerja berpengaruh positif dan signifikan terhadap OCB guru SMP di Kecamatan Jerowaru sebesar 31,9\%. 5) Kepemimpinan transformasional kepala sekolah, dan kepuasan kerja secara simultan berpengaruh positif dan signifikan terhadap OCB guru SMP di Kecamatan Jerowaru sebesar 52,5\%.

${ }^{24}$ Luthans, F. 2006. Perilaku Organisasi. (Alih Bahasa V.A Yuwono, dkk), Edisi Bahasa Indonesia. Yogyakarta: ANDI. 


\section{Saran}

Berdasarkan hasil penelitian, saran peneleliti adalah 1) kepala sekolah hendaknya mengefektifkan aspek-aspek kepemimpinannya, meningkatkan indikator kepuasan kerja guru yang belum maksimal sehingga dapat meningkatkan OCB guru, 2) guru perlu didorong untuk meningkatkan OCB yang tinggi agar dapat menunjang efektivitas pencapaian tujuan pendidikan di sekolah. Oleh karena itu, faktor-faktor yang dapat meningkatkan OCB harus mendapat perhatian seperti kepemimpinan kepala sekolah dan kepuasan kerja dan 3) hasil penelitian ini dapat digunakan sebagai referensi bagi peneliti dalam kajian mengenai kepemimpinan transformasional kepala sekolah, kepuasan kerja, dan perilaku kerja ekstra guru dengan memperhatikan variabelvariabel lain seperti variabel moderator, variabel kontrol dan variabel terikat yang belum dilakukan dalam penelitian ini.

\section{DAFTAR PUSTAKA}

Ali, Nazim., Ali, Shahid., Ahsan, Anjum., Rahman, Wili., Kakakhel, Shahid Jan. 2014. "Effects of Leadership Styles on Job Satisfaction, Organizational Citizenship Behavior, Commitment and Turnover Intention (Empirical Study of Private Sector Schools' Teachers)". Life Scince Journal. Vol.11 No 4(s).

Bidang Pendayagunaan dan Pelayanan Data dan Statistik Pendidikan dan Kebudayaan. 2016. "Analisis Sumber Daya Manusia Pendidikan Dasar dan Menengah 2015/2016. Di akses Maret.

Firmansyah, Farid. 2008. Pengaruh Lingkungan Kerja, Kompensasi, dan Kepemimpinan terhadap Kepuasan Kerja guru dan Karyawan SMA Wachid Hasyim Surabaya. Tadris Jurnal Pendidikan Islam. Vol. 3 No.1.

Hoy, W.K., Miskel, C.G. 2014. Administrasi Pendidikan. Edisi 9. Yogyakarta: Pustaka Pelajar.

Ivancevich, J.M., Konopaske, R., Matteson, M.T. 2007. Perilaku dan Manajemen Organisasi Edisi Ketujuh. Jakarta: Penerbit Erlangga.

Lubis, M.S. 2015. "Pengaruh Iklim Organisasi Dan Komitmen Organisasi Terhadap Pembentukan Organizational Citizenship Behavior (OCB) Karyawan Dalam Rangka Peningkatan Kinerja". E-jurnal apresiasi ekonomi. Volume 3(2) 75-84. stie-yappas.ac.id/e-jurnalapresiasiekonomi/jurnal/322.pdf. 
Luthans, F. 2006. Perilaku Organisasi. (Alih Bahasa V.A Yuwono, dkk), Edisi Bahasa Indonesia. Yogyakarta: ANDI.

Nadeak, G.B. 2016. "The Effect Of The Cultural Organization, Leadership, Job Satisfaction, And Organizational Citizenship Behavior Lecturer In The Christian University Of Indonesia”. Jurnal Ilmiah Educational Management. Volume 7 Nomor 1. 1254-1262. pps.unj.ac.id/journal/jiem/article/view/216.

Nasra, M.A., Heilbrunn, Syibille. 2015. "Transformational Leadership And Organizational Citizenship Behavior In The Aarab Educational System In Israel”. Jurnal Educational Administration And Leadership.

Organ, D.W., et.al. 2006. OrganizationalCitizenship Behavior. California:Sage Publications, Inc.

Putranti, A.D., Kurniady, D.A. 2013. "Kontribusi Kepemimpinan Transformasional Kepala Tk dan Kepuasan Kerja Guru Terhadap Organizational Citizenship Behavior (OCB) Guru Tk Se-Kabupaten Kudus. Jurnal Administrasi Pendidikan. Vol. XVII No.1, 1-11

Rafizi. 2013. "Pengaruh Kepemimpinan Transformasional Dan Kepuasan Kerja Terhadap Perilaku Kewargaan Guru Sekolah Menengah Di Sungailiat, Kabupaten Bangka”.Tesis: Universitas Terbuka.

Rahman, Ulfiani. 2014. Kepuasan Kerja dan Organizational Citizenship Behavior Pada Guru Madrasah Aliyah Madani Alauddin Paopao Gowa Sulawesi Selatan. Jurnal Analisa. Vol. 21 No.1.

$\begin{array}{llll}\text { Rahmawati, } & \text { T. } & \text { Prasetya, } & \text { A. }\end{array}$ “Analisis Faktorfaktor yang Mempengaruhi Organizational

Rahmi. 2013. "Pengaruh Kepemimpinan Transformasional Terhadap Organizational Citizenship Behavior Dan Komitmen Organisasi Dengan Mediasi Kepuasan Kerja". Jurnal Manajemen Universitas Udayana. 331-350.

Robbins, S. \& Judge, T. 2008. Perilaku Organisasi EdisiKedua Belas. Jakarta: Salemba Empat:Jakarta

Sari, D.P. 2017. Organizational Citizenship Behavior (OCB) pada Guru SMPN Sub Rayon-02 di Kabupaten Semarang Ditinjau dari Jenis Kelamin. Institutional Repository. Satya Wacana Christian University.

Siregar, Edi.2011. Pengaruh Motivasi Kerja, Kinerja Individual, dan Sistem Kompensasi Finansial Terhadap Kepuasan Kerja. Jurnal Pendidikan Penabur, 16, h:81-93

Susilowati. 2009. "Pengaruh Kepemimpinan, Lingkungan Kerja, Pengembangan Karir, Komunikasi Dan Insentif Terhadap Kepuasan Kerja Guru Sma Negeri I Cawas Kabupaten Klaten”. Exellent. (2).1.pp. 1-23.

Tschannen-moran, M. 2003. "Fostering Organizational Citizenship In School: Transformational Leadership And Trust". Journal Of Educational Administration. Chapter 6.pp. 1-36 